\title{
Research on the Setting and Countermeasures of Interdisciplinary Electrical Platform Courses under the New Engineering System
}

\author{
Yuanyuan $\mathrm{Li} *$ \\ School of Electronic and Electrical Engineering \\ Shanghai University of Engineering Science \\ Shanghai, China
}

Bei Jiang

School of Electronic and Electrical Engineering Shanghai University of Engineering Science Shanghai, China

\author{
Zhijun Fang \\ School of Electronic and Electrical Engineering \\ Shanghai University of Engineering Science \\ Shanghai, China
}

Yumei Jian

School of Electronic and Electrical Engineering Shanghai University of Engineering Science Shanghai, China

\begin{abstract}
Shanghai University of Engineering Science (SUES) is the first batch of pilot universities for the ministry of education "excellent engineer education and training plan". SUES is also belong to the leading unit for the construction of new engineering projects in local universities and colleges. The education concepts are deepening the reform of education and innovating the model of talent training. The College of Electrical and Electronic Engineering (SEEE) builds an electrical discipline platform curriculum based on the planning of SUES's full credit system. These curriculums are covering six majors. This paper is based on the planning of emerging engineering education, and the requirement for the engineering education certification. Setting and Reform of the interdisciplinary electrical platform curriculum, SEEE have solved the problems of large-scale professional basic courses, lack of engineering training ability and so on. The exploration model of SEEE is first and foremost in SUES with certain typicality and representations. It also can become the demonstration for those universities and colleges of traditional engineering and emerging engineering.
\end{abstract}

Keywords-Emerging engineering education; Interdisciplinary; Electrical platform; Curriculum setting

\section{INTRODUCTION}

Since February 2017, the ministry of education has actively promoted the construction of emerging engineering education, and has successively formed the "Fudan Consensus", "Tianda Action" and "Beijing Guide". The Ministry of Education is fully committed to exploring the advanced Chinese model of engineering education and the Chinese experience to help to strengthen the construction of a country with higher education. It encourages colleges to evaluate the situation, anticipate, adapt and respond actively, and give full play to the grassroots level initiative. Colleges should explore the new concept of practical engineering education, the new structure of discipline and specialty, the new mode of talent cultivation, the new quality of education and teaching and the new system of

The authors thank the Project of Shanghai higher education association: "study on the setting and countermeasures of electric platform courses of cross-disciplinary subjects under full credit system" (GJEL1818). classified development[1].

On May 2, 2018, general secretary Xi Jinping reiterated that higher education is an important symbol of a country's development level and potential in his speech at the Peking University Teacher-Student Symposium[2]. On June 21, 2018, minister of education Chen Baosheng proposed at the Undergraduate Education Work Conference of the National Higher Education Institutions of the New Era, insisting on "People-oriented" and promoting "Four Regresses". He also proposed that we should speed up the construction of highlevel undergraduate education, comprehensively improve the personnel training, and create a new generation worthy of the great task of national rejuvenation [3]. Wu Yan, director general of the ministry of education, also pointed out that higher education should have new ideas, new contents, new standards and new methods[4].

Shanghai University of Engineering Science (SUES) is the chairman unit of the School of Excellence in Engineering Education of Local Universities and Colleges, at the same time; it is also the lead contact unit for research and practice of new engineering in local universities and the first demonstration base for cooperation between industry and university in China. In recent years, SUES has actively integrated into the development strategy of building a globally influential science and innovation center in Shanghai. It has accelerated the pace of its transformation and upgrading, such as laid out new engineering majors, continuously promoted the certification of engineering education and focused on cultivating applied talents of higher engineering. These measures are aimed at building characteristic universities with high-level engineering applications[5]. According to the talent training objectives of the SUES, The College of Electrical and Electronic Engineering(SEEE) has always been committed to the training of excellent electrical and information engineers. It always pays attention to the forefront of international engineering technology, and takes the initiative to meet the national strategic needs, so as to serve the development of industrial 
enterprises better. SEEE is a college gathering high-end talents and training characteristics. It has trained a large number of high-level engineering technology and engineering management talents for Shanghai and even the whole country.

Under the guidance of national and university policies, SEEE has made some achievements in the exploration of new engineering construction. It now has four undergraduate majors, including computer science and technology, automation, electrical engineering and its automation, radio and television engineering. In 2017, our application for data science and big data major was approved, which makes SUES becomes the first batch in Shanghai to have this major. In 2018, the automation (artificial intelligence) experimental class became the first pilot major in SUES and successfully enrolled students. At the same time, the three majors of radio and television engineering, electrical engineering, automation and automation of SEEE were awarded the third, fourth and fifth batch of applied undergraduate pilot majors of Shanghai Municipal Education Committee, and applications for the 2019 engineering education certification in automation and computer science and technology have been accepted.

In the construction of new engineering majors in China, especially in the implementation and development of engineering education certification in line with the Outcomesbased Education (OBE) teaching concept, problems such as excessive division of disciplines and majors, insufficient mathematical foundation, insufficient engineering training, lack of international vision and weak cross-cultural communication ability have gradually emerged[6]. After years of development, SUES has formed a multi-disciplinary and comprehensive development trend.

However, there are still many problems to be solved, such as how to integrate the old and new professional curriculum resources, how to use the high quality teaching resources to improve the students' ability of engineering training and how to make all subject curriculum more effectively. Based on the teaching structure of the school and the professional setting of the school, this paper explores and studies the setting method of the interdisciplinary and cross-disciplinary electrical platform courses under the full credit system, revises and improves the training plan, and puts forward feasible construction ideas and plans for the construction of the interdisciplinary and cross-disciplinary electrical courses under the emerging engineering education.

\section{REVIEW OF ELECTRICAL COURSE SYSTEM UNDER TRADITIONAL MODE}

Since the implementation of the full credit system in SUES, the training plan formulated by SEEE can realize the intertransfer of engineering majors in the second semester of the first year and the inter-transfer of electrical majors in the second semester of the second year. The total credits of the four traditional engineering majors in SEEE are the same, and the training plan is relatively uniform. After exploration in recent years, our cultivation plan has the following problems:

\section{A. The cultivation of general courses and comprehensive design ability is not perfect}

General courses include advanced mathematics, physics, English and ideological and political courses, which can meet the engineering requirements. But both of the emerging engineering education and certification of engineering education have higher requirements on cutting-edge knowledge professional background and direction, engineering ethics, environmental protection and other aspects. In addition, the requirements for graduation set strict requirements on comprehensive design ability, namely the ability to solve complex engineering problems. Therefore, the original training plan fails to reflect the above content well.

\section{B. The core curriculum of each major is not uniform}

There are 4 core curriculums in the original training plan, which are automatic control theory, communication principle, object-oriented programming, and electrical engineering; all of them are 4 credits. They effectively achieved the initial unification of core courses. However, in our implementation process, there was still the situation that the major limited the selection of core courses.

\section{The features of subjects and the intersections between subjects are not obvious in the curriculum}

Basic courses contain 12 optional courses, including computer introduction, the material thermodynamics, singlechip computer application technology, automatic control theory, the EDA technology and practice B, Linux operating system, etc., all of which are 2 credits. The professional courses of each major include compulsory courses and elective courses, but in the actual implementation process, it fails to fully reflect the interdisciplinary in the large electrical platform.

The template is used to format your paper and style the text. All margins, column widths, line spaces, and text fonts are prescribed; please do not alter them. You may note peculiarities. For example, the head margin in this template measures proportionately more than is customary. This measurement and others are deliberate, using specifications that anticipate your paper as one part of the entire proceedings, and not as an independent document. Please do not revise any of the current designations.

\section{SPECIFIC RESEARCH METHODS AND IMPLEMENTATION PROCESS}

\section{A. Architecture}

Under the condition of emerging engineering education, SEEE needs to upgrade the traditional majors with engineering education certification as the standard. We have added data science and big data professional and artificial intelligence experimental classes. Today's electrical platform architecture emphasizes the practicability, cross-cutting and comprehensiveness of the disciplines, highlighting the close integration of new technologies such as computers, big data, information communication, and intelligent control with traditional industrial technologies.

Therefore, the research, adjustment and reform of interdisciplinary training programs and curriculums are 
steadily advancing, involving 6 traditional and emerging engineering education majors.

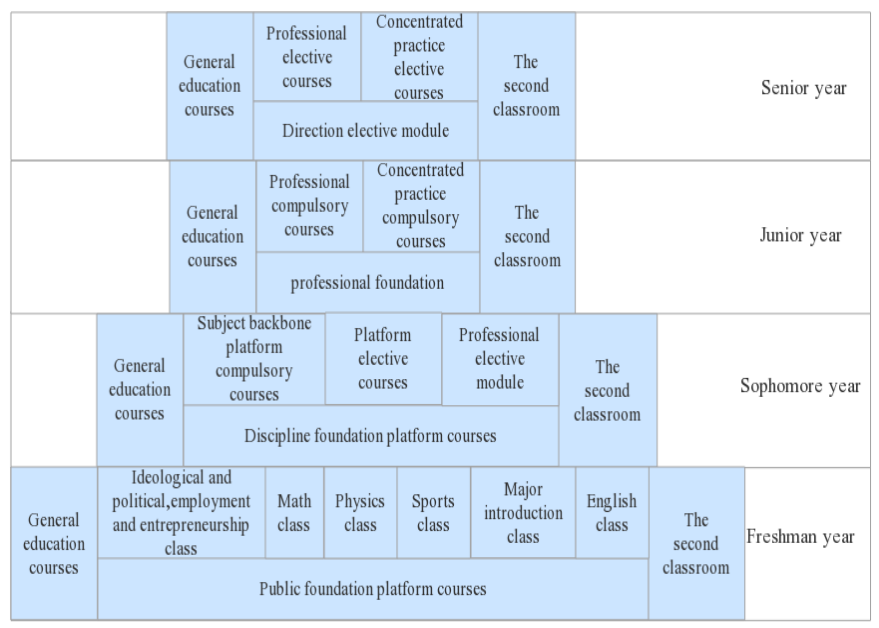

Fig.1. Structure diagram of the electrical platform + module curriculum

\section{B. The basic framework of research and key difficulties}

Considering the composition of the interdisciplinary curriculum system and the six majors of the college, the overall allocation of the revised curriculum credits for the 2019 college students is shown in Table I.

TABLE I. CREDIT DISTRIBUTION TABLE OF TRAINING PLAN COURSES FOR CLASS 2019

\begin{tabular}{|c|c|c|c|}
\hline \multirow{2}{*}{ Class types } & \multicolumn{3}{|c|}{ Development plans } \\
\cline { 2 - 4 } & Credits & $\begin{array}{c}\text { Studying } \\
\text { semesters }\end{array}$ & $\begin{array}{c}\text { The scope of } \\
\text { major change }\end{array}$ \\
\hline General courses & 61.5 & $\begin{array}{c}\text { Freshmen } \\
\text { year and } \\
\text { sophomore } \\
\text { year }\end{array}$ & $\begin{array}{c}\text { All engineering } \\
\text { majors in the } \\
\text { university }\end{array}$ \\
\hline $\begin{array}{c}\text { Electrical platform } \\
\text { courses }\end{array}$ & 36 & $\begin{array}{c}\text { Sophomore } \\
\text { year }\end{array}$ & $\begin{array}{c}\text { Electrical } \\
\text { platform of all } \\
\text { majors }\end{array}$ \\
\hline $\begin{array}{c}\text { Professional courses } \\
\text { Concentrated practice } \\
\text { teaching link }\end{array}$ & 32 & $\begin{array}{c}\text { Junior year } \\
\text { and } \\
\text { Senior year }\end{array}$ & $\begin{array}{c}\text { Junior year } \\
\text { and } \\
\text { Senior year }\end{array}$ \\
\hline The second classroom & 4 & All years & \\
\hline Total & 169 & \multicolumn{2}{|c|}{} \\
\hline
\end{tabular}

The main revisions and highlights are as follows

1) We proposed to add an introduction course for electrical majors according to the requirements of engineering education certification, and make reasonable planning for the content of 16 hours of the course. We added comprehensive design courses, and coordinate the resources of each major to form a cross-professional research group.

2) We put forward the cross-professional core course with the core of automatic control theory, and form a system of four courses of data science and analysis, artificial intelligence foundation and embedded system introduction according to the development of new technology.
3) We proposed a plan to form two modules of platform compulsory and platform elective, and formulated a " $4+\mathrm{X}+\mathrm{Y}$ " course setting mode in the training plan to form a "professional core course + professional compulsory course + professional elective course" form.

\section{Specific implementation plan}

1) Add professional introduction and professional comprehensive design courses

We have added a one-credit electrical class introduction course to the general-level course. This course has a total of 16 hours, of which 8 hours are used to explore professional introductions and 8 hours are used for pocket experiments. This course is open to all freshmen. We will invite the first-line embedded engineers to teach with the classroom teachers in the pocket lab teaching session, and guide the freshmen through the platform to form a professional understanding and hands-on training. At present, more than 550 2018-grade students have participated and achieved good results. At the same time, we have added a professional comprehensive design in the concentrated practice teaching session for a period of 2 weeks. Guided by teacher topics and innovative projects throughout the college, students from all majors form a team of 4 people to enhance the interaction between disciplines.

\section{2) Building a basic platform course for electrical core} disciplines

Set up four core courses of automatic control theory, data science and analysis, artificial intelligence foundation, and embedded system introduction course. All the six majors of the college are compulsory. The sum of the credits for these four courses is 10 . In addition, it is necessary to cooperate with the professional teachers to improve the syllabus and explore how to fully reflect the basic, cutting-edge and contemporary nature of the curriculum under the interdisciplinary conditions.

3) Forming electrical interdisciplinary compulsory and elective modules

Form " $4+\mathrm{X}+\mathrm{Y}$ " professional curriculum pattern, which mainly includes four major required courses, $X$ interdisciplinary courses and Y subject course in specialty direction. The part of the course fully reflects the characteristics and direction of each major, formed a variety of professional features. At present, in the curriculum, automation and electrical engineering and their automation are realized; computer science and technology, data science and big data technology, and radio and television engineering are realized.

\section{CONCLUSION}

The original intention of building a cross-professional platform course is to integrate the traditional engineering major with the emerging engineering education major under the emerging engineering education system. We have gradually transformed from professional education to generalist general education, and we have considered ways to expand the foundation and knowledge of students. After the practice, SEEE has reestablished four traditional engineering majors and two emerging engineering education majors. It has explored how to improve the training programs and course outlines according to the requirements of engineering education certification and emerging engineering education 
under the interdisciplinary conditions. The outline reflects the basic, cutting-edge and contemporary nature of the curriculum. Through a four-year summary and a one-year revision, the new training program can fully meet the set of interdisciplinary electrical platform courses under the new engineering background. It can achieve the complementarity of the teaching environment and through the " $4+\mathrm{X}+\mathrm{Y}$ " professional curriculum and the adjustment of practical teaching links. This model is used as a pilot throughout the university. It has the typicality and representativeness of the integration of traditional engineering majors and emerging engineering education majors under the higher education system.

\section{REFERENCES}

[1] Denghua Zhong, "Connotation and action of new engineering construction" Higher engineering education research. China, vol. 03, pp. 7-12, 2017, (In Chinese).

[2] Jinping Xi, Speech at the symposium of teachers and students of Peking University. China, May 2018, (In Chinese).

[3] Baosheng Chen, Adhere to the four regressions to promote the construction of Chinese characteristics, the world level first-class undergraduate education. China, June 2018,(In Chinese).

[4] Yan Wu, "New engineering: the future of higher engineering educationstrategic thinking on the future of higher education," Higher education research. China, vol. 06, pp. 1-3, 2018, (In Chinese).

[5] Jianguo Xia, Jun Zhao, "On the reform and development of engineering education in local universities under the background of new engineering construction," Higher education research. China, vol. 03, pp. 21-25+71, 2017, (In Chinese).

[6] Qiubo Yang, Yiru Chen, "Action research on the transformation and upgrading of traditional engineering majors in universities with engineering superiority," Higher education research. China, vol. 06, pp. 23-26+70, 2018, (In Chinese). 